\title{
Notas sobre desigualdade e posse de escravos em Buenos Aires (1778)
}

\author{
Carlos Alberto Medeiros Lima ${ }^{1}$
}

\begin{abstract}
Resumo: Este artigo, baseado no recenseamento realizado em 1778 na cidade de Buenos Aires, aborda a estrutura de posse de escravos na cidade. Já se manifestavam altas taxas de crescimento econômico na urbe e na campanha circundante, mas o fim dos anos 1770 foi marcado por algumas dificuldades derivadas da guerra de Independência das colônias continentais inglesas da América do Norte e elas, embora não tenham sido sérias, afetaram em alguma medida a posse de escravos. Após uma breve comparação com o caso do Rio de Janeiro, a alta concentração da posse de escravos é relacionada à distribuição por gêneros dos cativos portenhos e aos tipos de domicílio, segundo vários critérios, chefiados pelos proprietários escravistas. $\mathrm{O}$ artigo também trata de temas relacionados à família escrava e à mestiçagem, com resultados articulados à preservação da natureza profundamente desigual da organização social e à centralidade do avanço rural que circundava a cidade.
\end{abstract}

Palavras-chave: Escravidão urbana; estrutura de posse de escravos; hierarquia social em Buenos Aires, 1778.

\section{Notes on inequality and patterns of slaveholding in Buenos Aires (1778)}

\begin{abstract}
Based on 1778 census information about Buenos Aires, this study deals with patterns of slaveholding in the city. High rates of demographic growth were experienced during the eighteenth century in the city and the surrounding region, although rates of economic growth were affected by the fact that the end of 1770s was a period of difficulties due to war, with impacts on the organization of slaveholding units. After a brief comparison with Rio de Janeiro, the high degree of concentration of slaveholdings is related to the sex structure of the slave population and to the type of dwelling possessed by their masters. The articles also deals with issues related to the slave family and to race mixture, relating the results to the preservation of the extremely unequal nature of social organization and to the centrality of rural advancement around the city.
\end{abstract}

Keywords: Urban Slavery; patterns of slaveholding; social hierarchy in Buenos Aires, 1778

Artigo recebido em: 13/10/2016

Artigo aprovado em: 07/04/2017

\footnotetext{
${ }^{1}$ Professor do Departamento de História e da Pós-Graduação em História da UFPR; doutor em História Social pela UFRJ; bolsista de produtividade em pesquisa - nível 2 - do CNPq email: carlima3@gmail.com
}

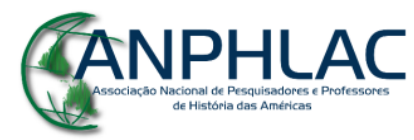

Revista Eletrônica da ANPHLAC, ISSN 1679-1061, №. 23, p. 185-218, Jul./Dez., 2017.

http://revista.anphlac.org.br 


\section{Introdução}

Os estudos sobre o cativeiro em Buenos Aires tratam bastante da questão do protagonismo escravo, com suas possibilidades e limites (GOLDBERG; MALLO, 1994; ROSAL, 1996; ROSAL, 2013; JOHNSON, 2007; SECRETO, 2010). Essas interpretações chamam muito a atenção para as instituições vigentes, mas também para a natureza da escravidão urbana. Enfatizam, além do mais, o fato de se ter tratado de uma sociedade com escravos (GOLDBERG, 2012), mais que de uma sociedade escravista, dando relevo às características da demanda pelo trabalho desses cativos, as quais também interferiam na conformação de suas vidas. ${ }^{2}$ Essas discussões animaram a busca por alguns relances acerca da estrutura de posse de escravos em Buenos Aires, pois essa consagrada ferramenta de análise sempre permitiu compreender aspectos importantes da demanda por trabalho escravo, dos formatos assumidos pela escravidão urbana e do contexto da vida cativa. A escravaria, além da rua, era um modulador essencial daquelas atividades, assim como das relações escravistas.

O modo como José Luis Moreno abordou a estrutura de posse de escravos na Buenos Aires de 1778 é engenhoso e extremamente pertinente, mas os projetos comparativos nos quais o presente artigo se insere tornam necessários alguns acréscimos. Baseando-se no mesmo recenseamento a ser usado aqui - depositado no Archivo General de la Nación e publicado com grande rigor, em 1919, pela Universidad de Buenos Aires -, Moreno optou por focalizar as ocupações dos cabeças de domicílios, verificando a proporção, para cada uma, dos fogos que apontavam para a posse de ao menos um escravo. Dessa forma, todos os de grandes comerciantes importadores e exportadores possuíam-nos, assim como a totalidade dos domicílios de grandes proprietários rurais. Quase todos os da alta hierarquia militar, administrativa e judiciária faziam-no. A participação dos escravistas entre os fogos dos outros funcionários, assim como no total dos domicílios de profissionais liberais, ficava ao redor dos três quintos ou dois terços, ao passo que, das casas de artesãos, comerciantes e pequenos proprietários rurais, uma em cada três, aproximadamente, tinha cativos. Por fim, entre

\footnotetext{
2 A historiografia diferencia "sociedades com escravos" de "sociedades escravistas" alertando para a circunstância de que só nas segundas o cativeiro baseava as atividades econômicas fundamentais para a reprodução dos grupos dominantes. Ver, por exemplo, GOLDBERG; MALLO, 1994.
} 
outros trabalhadores, os fogos escravistas eram muito mais raros. A média de escravos possuídos nos domicílios de cada grupo ocupacional (nesse caso, o Autor considera apenas os fogos escravistas de cada tipo de profissão) acompanhava as tendências quanto ao acesso à posse (MORENO, 1965, p. 158, 161).

A esmagadora maioria dos escravos referidos no recenseamento estava envolvida na labuta urbana, o que implica alguns cuidados. As discussões sobre a estrutura de posse de escravos apontam normalmente para o rendimento dessa análise como uma aproximação à estrutura dos patrimônios, à distribuição da riqueza e à hierarquia social vigente entre os proprietários, o que se faz observando não só as características dos escravistas, mas também aquelas dos escravos em cada um dos estratos formados pelo tamanho da posse (SCHWARTZ, 1988, p. 374; MOTTA; NOZOE; COSTA, 2004). No caso dessas cidades incrustadas em sociedades rurais, caso da borda atlântica da América Espanhola, muitíssimos dos escravos analisados não estavam envolvidos nas atividades que constituíam o motor dos processos centrais de crescimento e acumulação. Nesses termos, o que a análise da estrutura de posse de cativos permite ver quanto aos patrimônios é mais a capacidade de consumir serviços que a potencialidade para produzir, o que, segundo a leitura proposta neste trabalho, constitui a contribuição de Saguier (1989) e Mallo (2003, p. 114). É claro que muitos dos escravos portenhos efetivamente produziam, inclusive na agricultura de abastecimento, mas é difícil distingui-los dos cativos domésticos. Como no caso das análises sobre a vida comercial, a percepção de se ter tratado de sociedade marcada por forte caráter agrário necessita ser mantida como uma noção distante, mas onipresente e sempre incidente na interpretação das informações.

Outra utilidade do estudo da estrutura de posse de escravos levantada pela historiografia reside na visada que ele permite sobre efeitos de legitimação do cativeiro. Desde Schwartz, nota-se o aparente paradoxo de que, dentro de cada região, a distribuição da propriedade de cativos se mostrava ao mesmo tempo concentrada e inclusiva. Assim, quase todos os estudos notaram que a maior parte dos escravos pertencia a senhores que, segundo os padrões locais, eram grandes proprietários. Ao mesmo tempo, notou-se - e recorrentemente - que pequenos senhores constituíam a maior parte dos proprietários de escravos (FLORENTINO, 1997, p. 27-33). Assim, a propriedade de cativos se ligava a fenômenos de mobilidade social ascendente, de modo

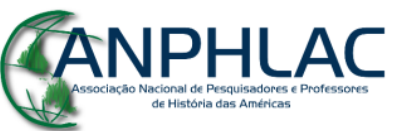

Revista Eletrônica da ANPHLAC, ISSN 1679-1061, №. 23, p. 185-218, Jul./Dez., 2017. http://revista.anphlac.org.br 
que uma a princípio simpática mobilidade social tomava a forma particularmente monstruosa do acesso não muito remoto à propriedade de seres humanos.

Pressupostos metodológicos serão enunciados na sequência. Por ora, importa deixar claro que o problema da demanda por escravos será abordado basicamente observando a importância das grandes escravarias, se as tiver havido, e as proporções de homens e mulheres na população cativa. Neste último caso, a motivação está em que a razão de sexo dá acesso à importância do tráfico de escravos e da emigração de cativos (juntamente com seus senhores). O tráfico produzia, como se sabe, maiorias masculinas na população escrava adulta, indicando forte demanda por seu trabalho. Uma composição mais equilibrada quanto aos gêneros denuncia frequentemente que o cativeiro deitava raízes na reprodução endógena das escravarias. Maiorias femininas na população significavam emigração de homens (ou remigração de africanos) e essa emigração indicia fraca intensidade da demanda por escravos. De fato, referindo-se à população negra de Buenos Aires na segunda metade do século XVIII, Silvia Cristina Mallo já faz referência à ruralização. José Luis Moreno também (MALLO, 2005, p. 8; MORENO, 1965, p. 168). Isso se relaciona à extrema volatilidade da demanda por escravos em Buenos Aires sugerida por Rosal. Segundo ele, a partir da abolição do tráfico de 1812, "la oferta de esclavos en el mercado porteño sufre una baja considerable; paralelamente, la caída de la demanda parece haber sido más aguda aún que la de la oferta" (ROSAL, 1994, p. 4).

É preciso também enfatizar não ser possível dizer que a demanda por escravos era fraca apenas por haver mais escravas que escravos, como se escravas não produzissem com seu trabalho. Ao contrário, já está sobejamente demonstrado que cativas trabalhavam produtivamente, e muito, inclusive na cruel lavoura canavieira (SCHWARTZ, 1988, p. 128-129), de modo que a razão de sexo indicia aspectos da demanda apenas devido ao fato de ela indicar processos migratórios.

\section{Os documentos}

Os padrones considerados derivaram de decisão de 1776 do ministro José Gálvez, tendo a medida sido aplicada ao Rio da Prata pelo vice-rei Juan José Vértiz y Salcedo em agosto de 1778 (LÓPEZ, 2016). Vértiz retornava então ao governo, após ter

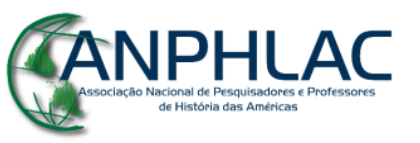

Revista Eletrônica da ANPHLAC, ISSN 1679-1061, №. 23, p. 185-218, Jul./Dez., 2017. http://revista.anphlac.org.br 
sido governador entre 1770 e 1776, tendo a gestão do já então vice-reinado sido exercida provisoriamente por Pedro de Cevallos. Afirma-se que o objetivo central do recenseamento teria sido mesmo o de viabilizar o governo (WAINER, 2010, p. 75). Essa tônica talvez fomentista pode ser contrastada com aquela dos padrones de 1744 , que parecem ter objetivado avaliar a capacidade de mobilizar homens armados, para além de conhecer os padrões de assentamento da população, o que talvez também respondesse a preocupações com a defesa (MORENO, 1989, p. 266-267).

Em geral, o recenseamento, que os historiadores consideram muito abrangente, usa as seguintes categorias de cor, condição e procedência, misturando um pouco todos esses elementos: espanhol, francês, inglês, índio, mestizo, mulato, mulato português, negro, português e suíço. Referindo-se a censos, López sustenta que no final do século XVIII as estratégias de controle de não brancos levaram à multiplicação das distinções sutis entre categorias sociorraciais, em lugar da antiga delimitação de "castas libres" (LÓPEZ, 2006). As distinções podem ter se tornado sutis, mas nem de longe se aproximaram daquilo que a nossos olhos pudesse ser tido por precisão. Além disso, deve-se lembrar que as categorias usadas no recenseamento foram marcadas pela virada nas percepções dominantes acerca dos pobres que Jorge Gelman verificou na comparação entre o começo e o final do século XVIII. No início deste, pobres eram vistos como "vagos, faltos de família y mendigos dignos de caridad", ao passo que, no fim do mesmo século, a percepção dominante passara a vê-los como "un obstáculo al crecimiento económico", condenando-os "como criminales" (GELMAN, 2005, p. 469).

Em geral, como precisamente assinalou Moreno, a falta de definição acerca das ocupações era muito grande, desestimulando o uso dos dados lançados (MORENO, 1965, p. 156). Até a atribuição de idades apresenta dificuldades, embora se trate de problema absolutamente normal nos censos antigos: no que toca às pessoas livres, $24 \%$ das idades terminavam em zero, percentagem que, quanto aos escravos, chegou a $33 \%{ }^{3}$

\footnotetext{
${ }^{3}$ Quanto à situação nos domicílios de corresidentes não aparentados aos cabeças, as categorias usadas são as seguintes: agregado, agregado criado, agregado livre, órfão, agregado órfão, livre, criado livre, agregado dependente, aprendiz, assistente na casa, bastardo, conchabado, criado branco, dependente, donado, livre agregado, livre conchavado, mozo, peon e sirvienta. Especialmente no caso de algumas ordens religiosas, a identificação de escravos enquanto tais parece ter sido problemática. Como exemplo, veja-se o caso dos 47 negros e mulatos no convento dos franciscanos e das 43 pessoas igualmente classificadas dessa maneira, quanto à cor, no dos dominicanos. Não se reportaram escravos nessas instituições, e todas as noventa pessoas supramencionadas foram tratadas como criados. Os bethlemitas, por outro lado, e como se sabe, não tiveram nenhuma dificuldade em classificar os negros e mulatos de
} 
Há uma grande lacuna de informação em uma parte realmente importante do recenseamento, abarcando cerca de sete mil pessoas, entre livres e escravos: o Padron general de la quarta parte de Buenos Aires, cometido, por su itt. ${ }^{\text {re }}$ Cavildo, a Don Francisco Antonio de Escalada foi negligente em separar os domicílios uns dos outros, impedindo a realização de algumas análises sobre esses habitantes, conforme será apontado toda vez que a anomalia atrapalhar a discussão. Não é possível deixar de assinalar que a ocorrência disso tem alguma gravidade, pois, se no conjunto da população os escravos compunham cerca de um quinto das pessoas, nessa parte às vezes desconsiderada nas discussões subsequentes a parcela escrava ficava em torno de três décimos. Felizmente será possível trabalhar com o conjunto do recenseamento na maior parte das vezes; somente os momentos nos quais a análise passar pelas características dos domicílios será preciso usar essa amostra mais restrita.

As avaliações já realizadas por historiadores quanto ao censo de 1778 produziram totais diferentes. Isso não se deveu a erros cometidos pelos profissionais, mas antes a uma série de ambiguidades contidas na própria fonte. Era frequente, por exemplo, que nomes indicados como o de cabeças de domicílio fossem apenas repetições de referências a pessoas já descritas, indicando terem controlado um segundo ou terceiro fogo. A isso, podem-se acrescentar, como exemplificação adicional, os casos já mencionados dos criados que talvez fossem escravos. Assim, propõem-se aqui algumas totalizações as quais certamente discrepam um pouco de contagens anteriores, mas que se mantêm em ordens de grandeza semelhantes. A população total teria sido de 24737 pessoas, 5131 das quais escravizadas $(20,7 \%)$.

\section{Contexto}

Em 1778, marcava a cidade a recente transformação em vice-reinado, melhorando muito a posição de seus negociantes quanto à disputa, que vinha de meados do século, com mercadores limenhos pela preponderância em relação ao interior da

sua casa como esclavos para el servicio (UNIVERSIDAD DE BUENOS AIRES, 1919, p. 571-580). Um problema importante da fonte é a relativa ausência de indicação de profissões e origens para os escravistas; e, quanto à origem, ressalta-se basicamente a ausência de informação sobre o nascimento na Espanha, na América, na região platina ou na própria Buenos Aires. Também faz falta a indicação da procedência dos escravos.

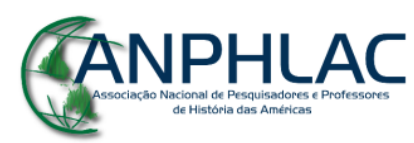

Revista Eletrônica da ANPHLAC, ISSN 1679-1061, №. 23, p. 185-218, Jul./Dez., 2017. http://revista.anphlac.org.br 
atual Argentina e ao Alto Peru (cf. ODDONE, 1982, p. 283, que usa como marco "la política que adopta Cevallos a partir del auto de libre internación de frutos [1777]”).

Segundo Sandra Olivero, desde 1744 a cidade vinha se definindo por uma topografia peculiar, com quatro áreas diferenciadas:

\begin{abstract}
el centro, área que rodeaba a la Plaza central donde se localizaban los sectores del gobierno, eclesiásticos y comerciantes; los suburbios, dos áreas al norte y al sur separadas del centro de la ciudad por la zanja de las Catalinas al norte y la zanja del Auto al sur -, barrios semiurbanos ocupados fundamentalmente por artesanos. Por último, las quintas, un anillo de chacras que rodeaban a la ciudad y que irradiaban a lo largo de los tres caminos principales hacia el norte, oeste y sur. (OLIVERO, 2007, p. 222)
\end{abstract}

A descrição de Jumar e Paredes (2008, p. 44) dá ainda mais lugar às projeções rurais da cidade durante o século XVIII:

\begin{abstract}
La traza central de Buenos Aires estaba delimitada por los zanjones de Matorras al norte y del Hospital al sur. El núcleo poblacional en expansión en el siglo XVIII fue el Alto de San Pedro, que era el barrio del puerto, el lugar del almacén de pólvora y del horno de ladrillos, y allí llegaban las carretas provenientes de campaña sur. El sector de la campaña norte comprendía desde el arroyo del Medio hasta el partido de la Costa (San Isidro o Monte Grande). La campaña sur la formaba el pago de la Magdalena, con una extensa costa que iba desde los límites de Buenos Aires hasta la desembocadura del río Salado. A lo largo de su costa había una cantidad considerable de desembarcaderos, como Quilmes, Ensenada, Punta Lara, La Balandra, Río Santiago, Río Samborombón y el mencionado Salado.
\end{abstract}

O crescimento da cidade no fim do período colonial tomava, entre outras, a forma da constituição de subúrbios, onde era possível atividade rural (REITANO, 2010, p. 104-105). Este último ambiente de chácaras é tratado por Fradkin como algo que expressava o poder da comunidade mercantil portenha, podendo ter-se iniciado já no século XVI, vinculado ao abastecimento e à provisão de produtos necessários à organização do transporte. Esse mundo de grandes propriedades, além do mais, estender-se-ia na direção da Banda Oriental (FRADKIN, 2000, p. 251; GELMAN, 1996, p. 98, 114, 123). Isso será importante adiante, quando for abordada a estrutura de posse de escravos. Por ora, vale deixar ressaltado o crescimento urbano, manifesto no fato de que, por volta de 1778, Buenos Aires estava dividida em seis cuarteles, ou paróquias (REITANO, 2010, p. 173).

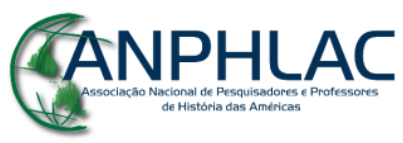

Revista Eletrônica da ANPHLAC, ISSN 1679-1061, №. 23, p. 185-218, Jul./Dez., 2017. http://revista.anphlac.org.br 
Processos de crescimento ocorriam desde, especialmente, os meados do século. Susan Socolow enfatiza particularmente processos políticos, vinculados à necessidade sentida pela Coroa de resguardar sua fronteira com as possessões portuguesas. Isso teria incrementado o fomento à radicação de colonos, elevando a importância de um mercado interno. O período iniciado em 1750 teria aumentado a importância dessa reação a disputas metropolitanas e coloniais. Acrescenta-se a atenção renovada à consolidação de elites pelo fato de que a expulsão dos jesuítas, de 1767, teria, segundo Socolow, criado uma espécie de vazio de poder. Mas o crescimento de uma poderosa comunidade mercantil já vinha tendo efeitos políticos, econômicos e na demanda ligada ao mercado interno desde a primeira ou segunda década do século (SOCOLOW, 1991, p. 13). A interpretação política do crescimento da cidade talvez também seja importante no raciocínio de Osvaldo Otero, que enfatiza muito, na caracterização de Buenos Aires do fim do século XVIII, ter-se tratado de "una ciudad en la frontera del imperio hispano", estando esta marcada por projetos de engrandecimento ligados ao modo de implantação da administração espanhola (OTERO, 2016).

Há ainda explicações sociais, e nesse sentido é importante lembrar aquilo que Javier Kraselsky denomina centralização corporativa, fenômeno que teria ocorrido no final do século XVIII. Ele faz referência à constituição, em realidade informal, de juntas de comércio que na década de 1790 terminariam por ter relação com o estabelecimento do Consulado de Comércio. O autor data aquelas juntas de 1779, mas isso só pode ter resultado de uma crescente consolidação da atividade mercantil que vinha ocorrendo antes disso (KRASELSKY, 2012). A própria concessão da criação de Consulados apesar de que o portenho só se instituísse nos anos 1790 - era articulada pelas autoridades monárquicas ao "comércio livre" estabelecido em 1778 (CRUZ BARNEY, 2001, p. 68), prova de que, apesar da competição limenha e das mudanças institucionais dadas pela criação do Vice-Reinado, Buenos Aires manteve durante toda a segunda metade do século XVIII sua ligação com Potosí.

Socolow, Saguier, Gelman e Garavaglia acrescentam à expansão para a Banda Oriental que a consolidação pré-1777 da comunidade comercial portenha implicou avanço do domínio mercantil (crédito) na direção do litoral dos rios, no limite até o Paraguai, especialmente após a expulsão dos jesuítas. Isso podia atingir fazendas que, mesmo que jesuítas, eram de gado, pelo menos em Yapeyu (SAGUIER, 1993, p. 70-71;

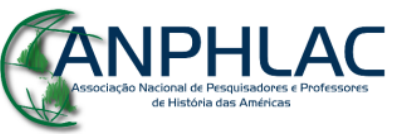

Revista Eletrônica da ANPHLAC, ISSN 1679-1061, №. 23, p. 185-218, Jul./Dez., 2017. http://revista.anphlac.org.br 
GELMAN, 1996, p. 82; GARAVAGLIA, 1978, p. 468-470). Para citar um exemplo fundamental, era extremamente abrangente a lista de praças com as quais Domingo Belgrano mantinha relações durante a segunda metade do século XVIII, pois passava pelo Rio de Janeiro e pelo Rio Grande do Sul, pela Banda Oriental e o Paraguai, mas também pelo litoral dos rios, obviamente, além do Noroeste da atual Argentina (GELMAN, 1996, p. 29). A variedade indica que boa parte dessa expansão tinha a ver com o financiamento e o encaminhamento mesmo de atividades agrárias.

O relato de Azcuy Ameghino e Birocco (1998, p. 58) sobre a extensão da campanha pela altura da criação do Vice-Reinado ou um pouco depois indica que ela mal chegava a "uma quinta parte da superfície atual de Buenos Aires, recostada sobre os rios Paraná e da Prata". Não penetrava mais do que "cem quilômetros rumo ao interior do território, com uma fronteira que, por volta de 1782, tendia a se afirmar ao norte do rio Salado". Esses terrenos dividiam-se "em duas faixas paralelas, de parecidas, ainda que irregulares, dimensões". Uma delas pode ser vista como "campanha de antiga ocupação - a apropriada legalmente antes de 1754". A outra, "mais especificamente fronteiriça", estava em processo de aceleração do povoamento, "com a colonização da linha de fortins impulsionada pelo vice-rei Vértiz".

Desde a primeira metade do século havia grupos rurais que, se bem não eram muito numerosos, eram importantes e diversificados socialmente. Moreno (1989, p. 271) apontou a presença, na campanha bonaerense de 1744 , ao lado de algumas dezenas de grandes proprietários, de camada mais de oito vezes maior de pequenos e médios possuidores (quase quinhentos), para além de grupo de pequenos exploradores de terras alheias ou realengas, sendo este pouco mais numeroso que o de grandes proprietários.

Um dos elementos desse crescimento anterior já a 1776 foi muito capaz de afetar a vida urbana. Pode ter sido importante o incremento da migração de espanhóis para a cidade (REITANO, 2010), e há argumentos no sentido de que as transferências de peninsulares para as Américas durante o século XVIII já cabiam melhor, por seus efeitos, no modelo da imigração que no da colonização, embora se tratasse das migrações de Antigo Regime (mais masculinas e mais mercantis ou artesanais que camponesas; cf. COMADRÁN RUIZ, 1969, p. 77-78). Lucas Rebagliati chega a se referir à forte atração exercida por Buenos Aires sobre pobres peninsulares. Refere-se à cidade e à campanha como "tierra de alimentos baratos y altos salarios"

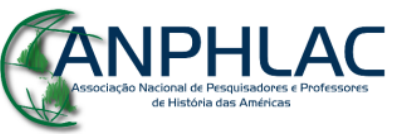

Revista Eletrônica da ANPHLAC, ISSN 1679-1061, №. 23, p. 185-218, Jul./Dez., 2017. http://revista.anphlac.org.br 
(REBAGLIATI, 2013, p. 11), sendo preciso lembrar a avaliação de que os preços do trigo e especialmente da carne foram mais baixos na atual Argentina que em todas as outras áreas sobre as quais se fez pesquisa relativa ao século XVIII considerado mais amplamente (ARROYO ABAD; DAVIES; VAN ZANDEN, 2012, p. 154). Assim, a população da cidade deve ter mais que dobrado entre 1744 e 1778, inclusive porque o conjunto urbano e rural constituiu a área de maior crescimento demográfico de toda a América Espanhola no fim do período colonial (OLIVERO, 2007; CUESTA, 2006, p. 214). Deve-se agregar ao raciocínio o fato de que esse crescimento não foi centrado unicamente na relação entre metrópole e colônia, pois, segundo os cálculos de Moreno para 1778, 34,2\% da população era passível de ser classificada como "de color", cabendo os restantes 65,8\% à "población blanca” (MORENO, 1965, p. 166).

É importante, no entanto, enfatizar que profundas mudanças que afetariam a presença cativa na cidade ainda não se haviam dado em 1778. 1776, com a criação do Vice-Reinado, e 1778, com o início das medidas do chamado "comércio livre", teriam constituído, para Martin Cuesta, o marco da "abertura legal do porto", de modo que ainda não haviam deslanchado efeitos no ano do recenseamento (CUESTA, 2007, p. 27). O tráfico de escravos ainda não tinha sido regularizado e estimulado pela Coroa (AZCUY AMEGHINO; BIROCCO, 1998, p. 52). As exportações de carnes salgadas da área platina só viriam a ganhar corpo a partir de meados dos anos 1780 (PEREDA VALDES, 1965, p. 84). Por outro lado, alguns instantes circunscritos de dinamização já haviam passado. Quanto ao tráfico de escravos, o auge da importância do contrabando vindo da Colônia do Sacramento parece ter estado nas décadas de 1740 e 1750 (ROCK, 1987, p. 42).

A segunda metade dos anos 1770 foi época de efeitos negativos da guerra de Independência das colônias continentais inglesas na América do Norte. A carne salgada atingiu pouco antes da realização do censo os preços mais baixos conhecidos em Buenos Aires durante todo o intervalo 1755-1795. Por outro lado, os preços do trigo vinham se recuperando após forte baque no início da década (1773 havia sido também o período de menor preço em toda a série relativa ao século XVIII). Os couros exportados passaram todo o período 1773-1781 caindo dramaticamente de volume, a partir de níveis bem altos atingidos no primeiro daqueles anos (CUESTA, 2007, p. 42, 47).

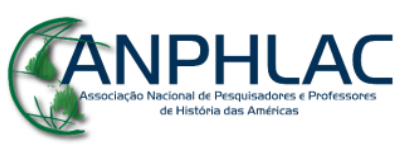

Revista Eletrônica da ANPHLAC, ISSN 1679-1061, №. 23, p. 185-218, Jul./Dez., 2017. http://revista.anphlac.org.br 
É fundamental lembrar que até mesmo o movimento e os valores envolvidos em algumas formas de apreensão de mercadorias contrabandeadas passaram por drástica redução durante o intervalo 1771-1777, como se lê no trabalho de Fernando Jumar e Isabel Paredes sobre os comisos, embora seja possível que isso tenha resultado do fato de que o intervalo anterior, o de 1740-1759, tenha sido o de mais intensa repressão à atividade ilícita (JUMAR; PAREDES, 2008, p. 40, 42). De modo análogo, embora a série de desembarques de escravos no Rio da Prata de Alex Borucki comece em 1777, a impressão com que se fica ao levá-la em consideração é a de que o nível da atividade traficante estava bem baixo no final dos anos 1770, passando a experimentar altas bruscas na década seguinte (BORUCKI, 2009, p. 4). O movimento anual de batismos de negros e pardos na paróquia da Inmaculada Concepción infletiu nitidamente para baixo a partir de 1770, segundo Carmen Benito Hierro (2015).

Até do ponto de vista dos créditos e débitos de mercadores parece ter havido algum tipo de inflexão durante a segunda metade dos anos 1770. Como mostrou Jorge Gelman, a fulminante ascensão de Domingo Belgrano quanto àquelas operações teve uma parada relativa por volta de 1776 (GELMAN, 1996, p. 27). Para que não haja exageros, no entanto, é importante ressaltar que, para o próprio Gelman, o conjunto das atividades de Belgrano aponta os anos 1776-1778 como anos normais, muito embora distúrbios econômicos verificados pelo autor tenham se manifestado em 1780-1782, e exatamente em virtude da guerra (GELMAN, 1996, p. 118).

Algumas informações têm um sinal mais ambíguo. Paralelamente à atividade comercial, no ambiente rural bonaerense (ao norte do rio Salado) dava-se um processo contínuo e sem sobressaltos de crescimento da extração de dízimos da agricultura (embora, evidentemente, o crescimento da parcela pecuária do mesmo imposto fosse muitíssimo mais rápido). Entre 1766 e 1800, segundo dados de Garavaglia e Djenderedjian, a cada dez anos a tributação da agricultura se acrescentava em cerca de $20 \%$ ou um pouco mais, suave e continuamente (DJENDEREDJIAN, 2008, p. 55). Além disso, Cuesta (2007, p. 43) esclarece que os anos de 1772 e 1777 foram de seca na região. Isso, embora fator que dificultava a vida, pode ter tido, ao aumentar os preços das reses, o efeito de empurrar para o agro escravistas que, como será visto, já tinham tendência a tomar esse rumo.

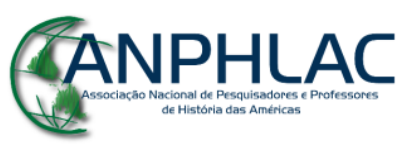

Revista Eletrônica da ANPHLAC, ISSN 1679-1061, №. 23, p. 185-218, Jul./Dez., 2017. http://revista.anphlac.org.br 
Houve paralelos no continente americano. A série chilena de preços do trigo elaborada por A. Ramón e J. M. Larrain atingiu em 1774-1778 o ponto mais baixo de toda a sua trajetória estendida de 1664 a 1808 (ROMANO, 1993, p. 110). Em Potosí, os preços da batata e do milho morocho despencaram durante a segunda metade dos anos 1770 (TANDETER; WACHTEL, s/d., p. 50-51). Salários passaram por movimento de decréscimo durante os anos 1770 na Nova Espanha e em Nova Granada, sabendo-se, pelo menos no primeiro caso, ter-se tratado de tendência duradoura (ARROYO ABAD; DAVIES; VAN ZANDEN, 2012, p. 156).

Os anos 1770 conheceram em diversas áreas conectadas com o Prata algum tipo de baque econômico relativo. $\mathrm{O}$ tropeço não chegou a interromper de modo consistente o movimento ascendente da segunda metade do século XVIII, mas no mínimo um freio temporário foi anteposto às exuberantes curvas de crescimento do período mais amplo. Isso pode ter tido efeitos em diversas características da população escrava, já que esta era peculiarmente sensível a movimentos de curto prazo, segundo se interpreta aqui a partir das análises de Florentino em relação ao Brasil (FLORENTINO, 1997). Esses efeitos tinham a ver, em outras partes, com o tráfico de escravos. Mas, mesmo onde ele não era tão decisivo na estruturação da população - caso de Buenos Aires -, ainda assim, as flutuações curtas tinham impacto. Não se deve esquecer que populações escravas eram singularmente plásticas quanto a adaptar-se a rápidos deslocamentos econômicos, no mínimo pela heteronomia de seus processos de fixação ou migração.

Segundo Hamilton, os preços em Castela atingiram os níveis anteriores à guerra dos sete anos em meados dos anos sessenta, mas interromperam esse crescimento logo em seguida, e apenas por volta da época estudada (o fim dos anos 1770) voltaram a aumentar (dados reproduzidos e avaliados por MERCADER; DOMÍNGUEZ, 1972, p. 31). São de se notar também os "platôs" que Vilar notou no comportamento dos anos 1770 de diversos indicadores dos direitos cobrados sobre a movimentação de mercadorias em Barcelona, lembrando ter o mesmo autor julgado que, por volta de 1780, o movimento portuário desta cidade já estava bastante dependente das trocas atlânticas (VILAR, 1982, III, p. 22-58). A série reconstituída por Michel Morineau das chegadas de metais preciosos americanos à Europa mostra, para os anos 1770, valores significativamente mais baixos que os de 1765-1769 e que os da década de 1780 (ROMANO, 1993, p. 94).

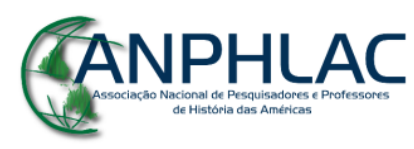

Revista Eletrônica da ANPHLAC, ISSN 1679-1061, №. 23, p. 185-218, Jul./Dez., 2017. http://revista.anphlac.org.br 
Quando da análise da distribuição dos escravos de Buenos Aires por gênero e por faixa de tamanho das escravarias, o que será realizado adiante, será necessário lembrar outra característica de contexto: como mostra Gladys Massé, durante o século XVIII, a cidade e a campaña da futura província de Buenos Aires realizaram uma espécie de contraponto. Até por volta de 1725, a população urbana cresceu muito mais rapidamente que a rural. Mas, a partir de então, o processo inverteu-se, e as áreas rurais passaram a apresentar avanço demográfico muito mais acelerado que o da cidade, embora esta continuasse a crescer rapidamente (MASSÉ, 2012, p. 150). A partir dos anos 1770 , inclusive, a taxa de crescimento da população urbana diminuiu um pouco, ao passo que a taxa relativa ao mundo rural cresceu ainda mais (CUESTA, 2006, p. 214).

\section{Sobre as posses de escravos}

Passa-se agora à discussão de aspectos da estrutura de posse de escravos. Inicialmente, procede-se a uma comparação com o caso do Rio de Janeiro, pois isso auxiliará a por as informações portenhas em contexto (tabela 1).

\section{Tabela 1}

Estimativas a respeito da distribuição dos domicílios segundo a posse de escravos (Rio de Janeiro e Buenos Aires, 1778-1805)

\begin{tabular}{lccc}
\hline & $\begin{array}{c}\text { Rio de Janeiro, 1789- } \\
\text { 1792, estimativa }\end{array}$ & $\begin{array}{c}\text { Rio de Janeiro, 1795- } \\
\text { 1805, estimativa }\end{array}$ & $\begin{array}{c}\text { Buenos Aires, 1778, } \\
\text { amostra parcial }\end{array}$ \\
\hline Sem escravos & 60,9 & 80,5 & 72,1 \\
1 a 2 escravos & 7,8 & 3,5 & 12,9 \\
3 a 4 escravos & 10,4 & 5,2 & 7,5 \\
5 a 9 escravos & 5,2 & 4,7 & 6,3 \\
10 a 19 escravos & 13,1 & 4,7 & 1,1 \\
20 ou + escravos & 2,6 & 1,4 & 0,1 \\
\hline Total & 100 & 100 \\
\hline Rio de Janeiro & & & 2,9 \\
Tamanho médio, considerando todos os fogos em 1789-1792 & 1,5 \\
Tamanho médio, considerando todos os fogos em 1795-1805 & 7,3 \\
Tamanho médio, considerando só os fogos escravistas em 1789-1792 & 5,5 \\
Tamanho médio, considerando só os fogos escravistas em 1795-1805 & 5 \\
Tamanho mediano, considerando só os fogos escravistas em 1789-1792 & 0,755 \\
Tamanho mediano, considerando só os fogos escravistas em 1795-1805 & 0,863 \\
Índice de Gini, todos os fogos, 1789-1792 & 0,399 \\
Índice de Gini, todos os fogos, 1795-1805 & 0,434 \\
Índice de Gini, fogos escravistas, 1789-1792 & & 5 \\
Índice de Gini, fogos escravistas, 1795-1805 & & \\
\hline
\end{tabular}

\section{GANPHLAC}

Revista Eletrônica da ANPHLAC, ISSN 1679-1061, №. 23, p. 185-218, Jul./Dez., 2017. http://revista.anphlac.org.br 
10+/10- (só escravistas) em 1789-1792*

\section{Buenos Aires}

Tamanho médio, considerando todos os fogos na amostra acima

Tamanho médio, considerando os fogos escravistas na amostra acima

Tamanho médio, considerando todos os fogos escravistas da cidade

Tamanho mediano, considerando os fogos escravistas da amostra acima

Tamanho mediano, considerando todos os fogos escravistas da cidade

Índice de Gini, todos os fogos da amostra acima

Índice de Gini, fogos escravistas da amostra acima

Índice de Gini, todos os fogos escravistas da cidade

0,409

10+/10- na amostra cima*

Obs.: Neste caso, não foi utilizada uma extensa parte do censo de Buenos Aires, o Padron general de la quarta parte de Buenos Aires, cometido, por su itt. ${ }^{r e}$ Cavildo, a Don Francisco Antonio de Escalada, pois os recenseadores, nesse padron, foram negligentes na delimitação dos domicílios. Outra dificuldade derivou de que o censo portenho anotou, naturalmente, as propriedades institucionais (ordens religiosas, por exemplo), ao passo que, no Rio de Janeiro, os inventários post mortem não contemplavam esse tipo de patrimônio. Os cálculos foram refeitos excluindo esse tipo de patrimônio do universo portenho observado, mas todos os indicadores permaneceram exatamente onde estavam, com diferenças ínfimas. Assim, descartaram-se aqui os resultados da análise baseada na amostra portenha expurgada das ordens.

* 10+/10- é o resultado da divisão do número de escravos pertencentes ao décimo superior dos senhores pela quantidade possuída pelo décimo inferior.

Fontes: Rio de Janeiro - LIMA, 2008, p. 98 (essa estimativa considerou a distribuição dos inventários por faixas de tamanho das escavarias, as dimensões da população escrava e a quantidade de fogos, de acordo com mapas de população do final do século XVIII); Buenos Aires - UNIVERSIDAD DE BUENOS AIRES, 1919.

Apesar de se estar comparando uma cidade com escravos com uma cidade escravista, as expectativas derivadas da consideração dessas diferenças podem ser matizadas a partir da comparação proposta na tabela 1. A distribuição portenha dos escravos pelas faixas de posse tinha algumas semelhanças com aquela vigente no Rio de Janeiro. Os plantéis ínfimos, de um ou dois cativos, eram, por outro lado, um pouco mais comuns. Mas ela voltava a ser comparável com o caso carioca no que se referia às escravarias com mais de dois e menos de dez escravos. Diferenças muito grandes mesmo eram aquelas verificadas no quesito grandes escravarias, o que, no mundo urbano, significava a proporção de pessoas donas de dez ou mais cativos. Nesse caso, a proporção no Rio era de cinco a quinze vezes maior que a vigente em Buenos Aires em 1778.

O tamanho médio das escravarias, no Rio, era bem maior que em Buenos Aires. O tamanho mediano era dois terços maior. Já os índices de Gini não eram tão diferentes assim, e volta-se a isso logo à frente. Tendo-se em mente que a parcela sem escravos era

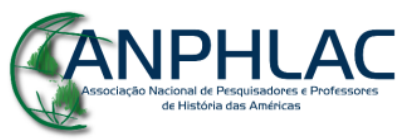

Revista Eletrônica da ANPHLAC, ISSN 1679-1061, №. 23, p. 185-218, Jul./Dez., 2017. http://revista.anphlac.org.br 
semelhante nos dois lugares, enxerga-se, em relação ao Rio, a voraz demanda por acumular escravos, aumentando o topo da distribuição. Em Buenos Aires, a base dos proprietários se alargava, sendo pouco discernível algum ímpeto por estabelecer grandes plantéis de escravos.

O índice de Gini pode tratar como semelhantes distribuições que contenham diferenças importantes. Segundo Wells (1974, p. 43) quando duas curvas de Lorenz que estejam sendo comparadas se cruzam, isso significa que elas apontam para distribuições diversas, embora os índices de Gini que as descrevem sejam muito parecidos. ${ }^{4}$ Em função disso, acrescenta-se à análise a relação entre as posses de escravos dos décimos superior e inferior dos senhores. Nesse ponto, as diferenças entre Buenos Aires e Rio voltam a ganhar relevo. O décimo superior dos escravistas na cidade brasileira era em torno de vinte vezes mais rico que o inferior. Na cidade portenha, ele era pouco mais que dez vezes mais abastado em escravos. As diferenças entre uma cidade escravista e uma cidade com escravos voltavam a aparecer com força. Decididamente, essa diversidade se manifestava na tendência a formar escravarias maiores no Rio e no fato de esses grandes plantéis explicarem mais as características da posse de escravos na cidade.

Ainda assim, merece ênfase a semelhança entre os indicadores gerais de desigualdade (o índice de Gini) do Rio e de Buenos Aires. Isso não chega a demonstrar, mas dá muito estímulo a se pensar em rotas diferentes para a constituição de universos desiguais em sociedades latino-americanas, ou em caminhos diferentes para chegar ao mesmo lugar: os graus de concentração da posse de escravos em sociedades com escravos e sociedades escravistas podiam assemelhar-se. Como ficou expresso, os pontos mais altos da distribuição (no indicador representado pela relação entre os décimos superior e inferior da distribuição) diferenciavam profundamente Buenos Aires e o Rio de Janeiro, ao passo que o conjunto da distribuição (segundo o indicador representado pelo índice de Gini) tornava as duas sociedades parecidas. No Rio de Janeiro, os dois décimos situados abaixo do superior eram mais robustos em comparação com este último e com todos os décimos situados abaixo. Em Buenos

\footnotetext{
${ }^{4}$ Índices de Gini, variando de zero (igualdade absoluta) a um (absoluta desigualdade), dão expressão numérica ao formato de curvas de Lorenz montadas com as percentagens acumuladas de possuidores de um dado ativo, ordenados dos menores para os maiores possuidores, e dos ativos possuídos por cada grupo de possuidores.
}

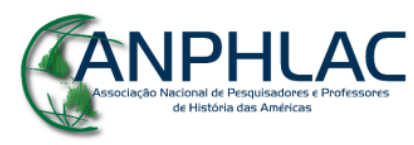

Revista Eletrônica da ANPHLAC, ISSN 1679-1061, №. 23, p. 185-218, Jul./Dez., 2017. http://revista.anphlac.org.br 
Aires, eram os cinco ou seis décimos inferiores que eram um pouco mais robustos em confronto com a elite.

Essa aparente contradição entre indicadores, com um sugerindo graus semelhantes de concentração e outro indicando enormes diversidades entre as distribuiçõos, deixa duas sugestões importantíssimas. A primeira é a de que parece ter havido rotas diferentes para que as duas sociedades chegassem a um mesmo ponto, qual seja o da desigualdade. A segunda, a de que essa desigualdade não radicava apenas na distância que separava a elite do restante da sociedade. Seu formato não era esse. Ela também se manifestava nas relações entre os vários grupos do meio da distribuição, fazendo lembrar a constatação de Moreno no sentido de ter existido em Buenos Aires uma clase media (MORENO, 1965, p. 162). Além disso, a desigualdade não derivava apenas de ter sido escravista ou "com escravos" cada uma dessas sociedades.

Além da semelhança dos indicadores de desigualdade, pode-se usar outros argumentos para defender não fazer sentido considerar que Buenos Aires fosse de alguma forma menos desigual que o Rio de Janeiro. Observe-se, por exemplo, a distribuição dos montantes pagos a título de alcabala por comerciantes portenhos em 1797..$^{5}$ As informações contidas no documento apontam para um índice de Gini de 0,607, muito alto para uma única ocupação, observação agravada pela relação entre os décimos superior e inferior da distribuição (10+/10-), que ficou em incríveis 68,5, compondo resultado muitíssimo maior que o verificado quanto à distribuição da propriedade de escravos no Rio ou em Buenos Aires. Como precaução destinada a matizar um pouco essa impressão de enorme diferenciação entre comerciantes, leve-se em conta que alcabalas eram cobradas tanto em transações de varejo quanto de atacado (ver, por exemplo, CUESTA, 2009, p. 42).

Era notável a preponderância feminina nas escravarias, conforme a tabela 2. Era notável, mas precisa de particularização, pois isso não se aplicava às maiores delas. As unidades com vinte ou mais cativos eram eminentemente masculinas, à proporção de três homens para cada duas mulheres. Atentando exclusivamente para os cativos com

\footnotetext{
5 As alcabalas constituíam o imposto decisivo do Antigo Regime hispânico, incidindo sobre transações comerciais. As informações provêm da "Distribucion de la Alcabala de Reventa de Menudeo, de Tiendas y Almacenes, respectiba al año pp. ${ }^{\circ}$ que los avajo firmados hemos echo por nombramientto de este R. ${ }^{1}$ Consulado com fecha de 20 dic. " prox. ${ }^{\text {mo }}$ pasado de 97", incluído em Archivo General de la Nación,
} Consulado de Buenos Aires - actas - documentos. Buenos Aires: Guillermo Kraft, 1947, p. 17-22. 
quinze anos de idade ou mais que isso, a preponderância numérica masculina continuava a não se verificar para todas as faixas de posse, mas nas grandes se exibia com força, chegando a dezenove homens para cada dez mulheres.

\section{Tabela 2}

Razão de sexo por faixa de tamanho das escravarias (Buenos Aires, 1778)

\begin{tabular}{lcc}
\hline & $\begin{array}{c}\text { Razão de sexo - todos os } \\
\text { escravos }\end{array}$ & $\begin{array}{c}\text { Razão de sexo - só escravos } \\
\text { com 15 ou mais anos }\end{array}$ \\
\hline 1 a 2 escravos & 63 & 58 \\
3 a 4 escravos & 78 & 68 \\
5 a 9 escravos & 81 & 77 \\
10 a 19 escravos & 90 & 90 \\
20 ou + escravos & 154 & 191 \\
\hline Total & 82 & 78 \\
\hline
\end{tabular}

Fonte: UNIVERSIDAD DE BUENOS AIRES, 1919.

Retomando brevemente a comparação com o Rio de Janeiro, aparece uma diferença abissal entre as duas cidades, mesmo que tenha sido semelhante a importância dos fogos escravistas no total dos domicílios. Essa diferença residia na escravidão urbana marcadamente feminina de Buenos Aires, comparada ao predomínio masculino na cidade do Rio de Janeiro, mais pronunciado até que o vigente nas regiões circundantes, de plantation (FLORENTINO, 1997, p. 272). Como foi visto, a razão de sexo portenha de 1778 pouco ultrapassava 80, ao passo que a carioca da década de 1790 ia fartamente além do patamar de cem entre os africanos e os crioulos.

Retomando, a esse propósito, uma terminologia consagrada, o Rio de Janeiro era uma cidade escravista. Buenos Aires, uma cidade com escravos. Só que, no Prata, eles eram muitíssimos. Arrisca-se aqui escrever que era a maior cidade com escravos da América do Sul. Para comparar novamente com uma cidade escravista, pode-se levar em conta que a população cativa urbana de Caracas deve ter variado de pouco mais de 5300 cativos em 1759 a 6169 em 1802. Na primeira dessas datas, cerca de um terço dos fogos da cidade continha escravos, compondo proporção extremamente alta (FERRY, 1989, p. 72, 217; MAGO DE CHÓPITE, 1997, p. 539). É possível que a população cativa da urbe venezuelana fosse composta por mais homens que mulheres. As pesquisas a que se teve acesso a esse respeito se preocuparam pouco em diferenciar as partes urbana e rural, mas, como as fronteiras entre um e outro âmbito eram fluidas até

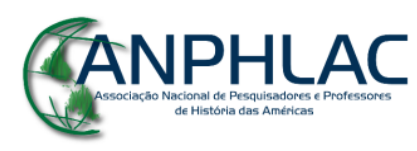

Revista Eletrônica da ANPHLAC, ISSN 1679-1061, №. 23, p. 185-218, Jul./Dez., 2017. http://revista.anphlac.org.br 
mesmo em Buenos Aires, o tom é mesmo esse: predomínio numérico masculino, ainda que menos pronunciado que no Rio de Janeiro.

Quanto a Lima, há poucas dúvidas. Em 1790, havia 8784 escravos, contando-se 4847 do sexo masculino e 3937, do feminino. O total de "almas" era de 61411 (DOERING; LOHMAN VILLENA, 1992, p. 143). É, inclusive, interessante observar que, na mesma cidade de Lima, mas quase dois séculos antes (em 1614), índios urbanos também podem ter sido predominantemente do sexo masculino (LOWRY, 1993). As cidades brasileiras mostravam fortes maiorias masculinas. Era o caso do Rio de Janeiro da década de 1790, como foi visto, sendo de se acrescentar que, neste caso, homens predominavam entre crioulos tanto quanto entre africanos (FLORENTINO, 1997, p. 272). Em Salvador, durante a década de 1810, repetia-se o caso, com cerca de 16 escravos do sexo masculino para cada dez escravas (ANDRADE, 1988, p. 195-197). Bogotá apresentava maiorias femininas, como Buenos Aires, mas sua população escrava era bem menor (VALENCIA VILLA, 2010, p. 248).

Como indicado, a maioria feminina em Buenos Aires é de fundamental importância. A reprodução endógena teria produzido números semelhantes de escravos e escravas. O tráfico de escravos, enormes maiorias masculinas (caso do Rio de Janeiro). Em Buenos Aires, no entanto, as mulheres predominavam largamente na população cativa. Para sugerir uma explicação, deve-se lembrar o que ficou escrito acima sobre o contraponto verificado na relação entre as populações da cidade e das partes rurais circundantes, a partir da análise de Massé, segundo a qual a população urbana cresceu mais rapidamente até o início do século XVIII, situação que se fez suceder, a partir de então, por avanço mais ligeiro - muito mais ligeiro - da população rural. Entre as décadas de 1720 e 1780, a população urbana pode ter crescido mais de três vezes, mas no mesmo intervalo os contingentes rurais podem ter aumentado em mais de oito vezes (MASSÉ, 2012, p. 148; ver também GUZMÁN, 2006). Tudo é consistente com a migração de homens escravizados da cidade na direção da ocupação de partes novas do campo circundante.

Ao redor da urbe a situação era inteiramente outra, portanto. Ou tornou-se completamente diferente após a liberação das importações de africanos dos anos 1780 e 1790. José Luis Moreno observou, quanto à campanha bonaerense de 1744, que, diferentemente do ocorrido com os tratados como brancos, dois terços da população "de

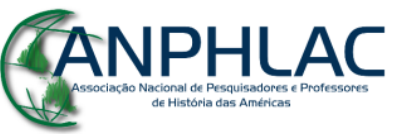

Revista Eletrônica da ANPHLAC, ISSN 1679-1061, №. 23, p. 185-218, Jul./Dez., 2017. http://revista.anphlac.org.br 
color" era do sexo masculino (MORENO, 1989, p. 269). Em 1813-1815, a população escrava rural de Buenos Aires era majoritariamente masculina dos dez anos para cima (GRUPO DE INVESTIGACIÓN EN HISTORIA RURAL RIOPLATENSE, 2004, p. 47). Incluir Santa Fé nos cômputos torna o número maior de homens ainda mais visível (VIGLIONE, 2007, p. 11). Escravarias nas estâncias existentes no século XVIII também eram fortemente masculinas (GELMAN, 1996, p. 70-72; HALPERIN-DONGHI, 1978, p. 454-456).

Essa tendência pode ser checada, sempre de modo não completamente conclusivo, através dos dados da própria cidade. Para isso, maneja-se mais uma amostra diferenciada. Dessa vez, circunscrevem-se os domicílios que receberam algum tipo de classificação quanto ao tipo de estabelecimento (tabela 3). Isso não se aplicou ao conjunto da cidade, mas é possível montar uma amostragem adicional com essas informações. De um lado, estavam os domicílios escravistas que foram chamados de casas pelos recenseadores. De outra parte, circunscrevem-se os fogos classificados como quintas, ornos, ranchos, rancherias e sitios, misturando-se chácaras, unidades propriamente agrárias e fornos de ladrilhos.

$\mathrm{Na}$ tabela 3, podem ser comparadas as distribuições por faixas de tamanho das posses nas unidades que receberam uma classificação como casas ou como outro tipo de estabelecimento. Consideraram-se as casas como unidades nitidamente urbanas. Os outros tipos eram basicamente formados por unidades rurais. As unidades respectivas, além de tendencialmente maiores, eram bem mais "plantacionistas", isto é, bem mais voltadas para o predomínio masculino vinculado à demanda por força física e a um caráter bem mais pronunciadamente "sanguíneo" dos cálculos relativos à acumulação.

Vê-se claramente que essas unidades escravistas externas ao mundo das casas tendiam a ser maiores. No mundo aparentemente urbano, predomínios masculinos só apareciam em unidades bem grandes para os parâmetros locais. Nesses casos, elas eram até mais pronunciadamente acumuladoras que as unidades ruralizadas que também fossem grandes. Inversamente, a associação entre predomínio numérico masculino e ruralidade fica bastante bem expresso no fato de que, no caso desses outros estabelecimentos, não se precisava nem mesmo chegar aos maiores tamanhos das escravarias para esbarrar com enormes taxas de masculinidade.

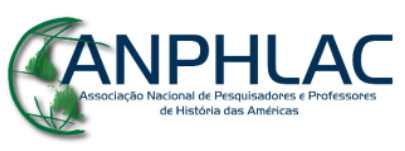

Revista Eletrônica da ANPHLAC, ISSN 1679-1061, №. 23, p. 185-218, Jul./Dez., 2017. http://revista.anphlac.org.br 


\section{Tabela 3}

Distribuição (\%) dos escravos por faixa de tamanho das escravarias e razão de sexo conforme os tipos de estabelecimento (Buenos Aires, 1778)

\begin{tabular}{lcccc}
\hline & \multicolumn{2}{c}{ Distribuição dos escravos } & \multicolumn{2}{c}{ Razão de sexo por faixa } \\
\hline Faixas de tamanho das escravarias & Casas & Outros tipos* & Casas & Outros tipos* \\
\hline 1 a 2 escravos & 21,2 & 16,9 & 54 & 193 \\
3 a 4 escravos & 28,8 & 22,3 & 82 & 218 \\
5 a 9 escravos & 40,5 & 33,5 & 83 & 268 \\
10 a 19 escravos & 8,0 & 12,8 & 124 & 138 \\
20 ou + escravos & 1,5 & 14,5 & 233 & 218 \\
\hline Total & 100 & 100 & 80 & 214 \\
\hline
\end{tabular}

* Quintas, ornos, ranchos, rancherias e sitios.

Fonte: UNIVERSIDAD DE BUENOS AIRES, 1919.

Um argumento negativo deve ser lembrado: o funcionamento do porto parece ter estado bastante desvinculado da escravidão portenha. Por outro lado, a combinação de "casas" predominantemente femininas com outros tipos de unidades ostentando maiorias masculinas deixa mais forte a suspeita de ter havido uma tendência consistente à transferência de escravos homens para áreas rurais fora da cidade. Afinal, é plausível que essas transferências de homens tenham ocorrido até mesmo para as unidades abastecedoras situadas no interior da abrangência administrativa da cidade.

Realiza-se agora uma aproximação à relação entre a composição dos fogos e a posse de escravos. A observação das razões de sexo conforme o tipo de domicílio e o tamanho das escravarias ajudará a ver se alguma dessas situações era mais ou menos propensa a se vincular mais intensamente ao mercado. Os fogos foram classificados levando em conta as relações que foram passíveis de identificação entre seus habitantes livres, como segue:

- A primeira categoria é a dos domicílios de senhores isolados de escravos.

- A segunda, a dos fogos que, além dos cativos, continham as famílias nucleares de seus cabeças.

- A terceira, a dos lares em que os senhores de escravos contavam com outros habitantes livres, sem que se possa saber se esses corresidentes eram ou não parentes dos cabeças ou aparentados entre si, do mesmo modo que não se pôde definir se as relações deles com os chefes de fogo eram mais simétricas ou mais desiguais.

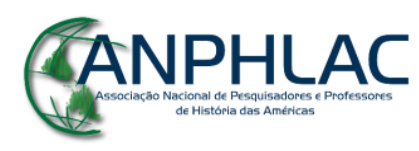

Revista Eletrônica da ANPHLAC, ISSN 1679-1061, №. 23, p. 185-218, Jul./Dez., 2017. http://revista.anphlac.org.br 
- Uma última categoria abrange os casos que não puderam ser incluídos em nenhum dos tipos anteriores (ordens religiosas, por exemplo).

A terceira categoria é problemática, mas a ausência de informação - ou a carência de disciplina quando a informação era fornecida - motivou algumas escolhas. A categoria foi montada deixando de lado se os corresidentes externos ao núcleo familiar do cabeça eram parentes ou não. Tampouco foi levado em consideração, dadas as dificuldades apresentadas pelas fontes de informação, se esses outros componentes apontavam para núcleos familiares quase que associados, se indicavam trabalhadores dependentes que não fossem escravos, ou se se tratava meramente de arranjos destinados a lidar com dificuldades de alojamento. Como as fontes não permitem sempre diferenciar essas situações, considera-se aqui, talvez sem muita justiça (mas também sem alternativas), que em todos esses casos a posse de escravos estava relacionada aos recursos materiais, políticos ou simbólicos provenientes desses arranjos de corresidência entre pessoas mais ou menos livres. A ideia, assim, é relacionar a posse de escravos com a possibilidade de que chefes de fogos reunissem grandes grupos de livres ao seu redor (quer estes fossem parentes, dependentes ou aliados).

É de se ressaltar que a amostra nesse caso é ainda menor que a usada na confecção da tabela 1. Nela, recorda-se, foram destacados os dados relativos a áreas da cidade onde os recenseadores foram negligentes em separar os domicílios uns dos outros, tendo elas sido referidas como a quarta parte de Buenos Aires, cometido, por su itt. $^{\text {re }}$ Cavildo, a Don Francisco Antonio de Escalada. No caso da tabela 4, foi necessário descartar também os dados de outra área da urbe, pois no caso desta havia forte oscilação em indicar se determinados corresidentes eram filhos do cabeça ou se eram agregados. Assim, excluíram-se as informações da vasta porção da cidade cujos dados foram recolhidos por

D. ${ }^{\mathrm{n}}$ Pedro Díaz de Vivar [...] en las Calles q. ${ }^{\mathrm{e}}$ miran de Leste a Poniente, cera al Norte, y de Norte a Sur, cera al Leste, con sus respectivas atrabiesas, y demás q. ${ }^{\text {e }}$ corresponde a la Formaz. ${ }^{\text {on }}$ del Cuadrilongo, con 4 cuadras de Longitud, y 12: de Latitud, uno y otro hasta encontrar los Mojones q. ${ }^{\mathrm{e}}$ dividen la Ciudad de su exido. (UNIVERSIDAD DE BUENOS AIRES, 1919, p. 581)

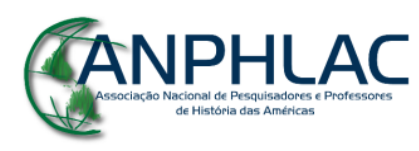

Revista Eletrônica da ANPHLAC, ISSN 1679-1061, №. 23, p. 185-218, Jul./Dez., 2017. http://revista.anphlac.org.br 
Conforme a tabela 4, os senhores isolados associavam-se às pequenas posses de escravos. As famílias nucleares sem outros livres em casa apareciam mais ligadas a posses um pouco maiores, mas ainda pequenas ( 3 ou 4 escravos, ou então entre 5 e 9 cativos).

Os senhores em cujas casas viviam outros livres externos a suas famílias nucleares, se as tivessem, associavam-se a posses um tanto maiores. A faixa modal era aquela de entre cinco e nove cativos, mas quase um quinto dos escravos pertencentes a esse tipo de senhor vivia em unidade de mais de 10 escravos.

\section{Tabela 4}

Distribuição dos escravos por faixas de posse conforme tipos de domicílio (Buenos Aires, 1778) - amostra parcial

\section{Distribuição percentual dos cativos}

\begin{tabular}{lcccc}
\hline $\begin{array}{l}\text { Faixas de } \\
\text { tamanho das } \\
\text { escravarias }\end{array}$ & $\begin{array}{c}\text { Domicílios de } \\
\text { senhores } \\
\text { isolados }\end{array}$ & $\begin{array}{c}\text { Domicílios de } \\
\text { senhores com } \\
\text { família nuclear, } \\
\text { apenas }\end{array}$ & $\begin{array}{c}\text { Domicílios de } \\
\text { senhores com outros } \\
\text { componentes livres, } \\
\text { parentes ou não }\end{array}$ & $\begin{array}{c}\text { Não se aplica } \\
\text { (ordens } \\
\text { religiosas, por } \\
\text { exemplo) }\end{array}$ \\
\hline 1 a 2 escravos & 41,5 & 20,5 & 16,4 & 2,3 \\
3 a 4 escravos & 26,5 & 35,4 & 24,7 & 3,5 \\
5 a 9 escravos & 18,7 & 36,1 & 39,3 & 54,0 \\
10 a 19 escravos & 13,3 & 8,0 & 17,6 & - \\
20 ou + escravos & - & - & 2,0 & 40,2 \\
\hline Total & 100 & 100 & 100 & 100 \\
\hline & & & & \\
N. absoluto de & 166 & 715 & 1617 & 87 \\
casos & & & & \\
\hline
\end{tabular}

Razões de sexo

\begin{tabular}{lcccc}
\hline $\begin{array}{l}\text { Faixas de } \\
\text { tamanho das }\end{array}$ & $\begin{array}{c}\text { Domicílios de } \\
\text { esenhores } \\
\text { isolados }\end{array}$ & $\begin{array}{c}\text { Domicílios de } \\
\text { senhores com } \\
\text { família nuclear, } \\
\text { apenas }\end{array}$ & $\begin{array}{c}\text { Domicílios de } \\
\text { senhores com outros } \\
\text { componentes livres, } \\
\text { parentes ou não }\end{array}$ & $\begin{array}{c}\text { Não se aplica } \\
\text { (ordens } \\
\text { religiosas, por } \\
\text { exemplo) }\end{array}$ \\
\hline 1 a 2 escravos & 103 & 39 & 63 & 100 \\
3 a 4 escravos & 57 & 74 & 85 & 200 \\
5 a 9 escravos & 107 & 103 & 77 & 96 \\
10 a 19 escravos & 450 & 68 & 79 & - \\
20 ou + escravos & - & - & 94 & 218 \\
\hline Total & 105 & 76 & 77 & 135 \\
\hline
\end{tabular}

Fonte: UNIVERSIDAD DE BUENOS AIRES, 1919.

Como era de se esperar, dois quintos dos escravos pertencentes a ordens religiosas ou a outras unidades institucionais viviam nas escravarias realmente grandes

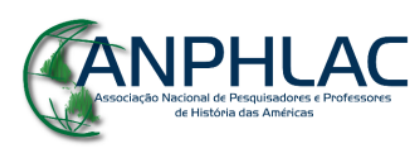

Revista Eletrônica da ANPHLAC, ISSN 1679-1061, №. 23, p. 185-218, Jul./Dez., 2017. http://revista.anphlac.org.br 
para os padrões portenhos (vinte ou mais escravos). Mais de metade pertencia a unidades em que cinco a nove pessoas eram escravizadas.

O panorama de escravidão eminentemente feminina, denotando sua natureza "estipendiária", era efetivamente generalizado. Mas, como foi visto em relação às unidades agrárias presentes na cidade, continha sempre algumas situações muito específicas, de forte ligação com o mercado.

Em alguns domicílios verificam-se casos de cativeiro um tanto mais "sanguíneo", voltado para processos talvez rápidos de acumulação. Na tabela 4, acima, isso pode ser visto no caso dos fogos de senhores isolados, quase geralmente os de mais altas razões de sexo, especialmente quando abrigassem escravarias maiores. Mas eles eram muito poucos. Isso se manifestou também em dois casos sem domicílio senhorial estruturado, ou seja, no da Ranchería de la Merced, tratada na tabela.

É de se notar que algo parecido verificava-se quanto aos livres. A quantidade de filhos por domicílio também acompanhava positivamente a riqueza, segundo Moreno (1965, p. 160), da mesma forma que a estabilidade matrimonial deve ter sido maior nos fogos dos mais ricos, o que Moreno observa levando em conta as proporções, por grupo social, dos casos em que faltava um dos cônjuges. A proporção desses casais com cônjuges faltantes reduzia-se quando aumentavam os sinais de abastança.

Os problemas da família e da reprodução endógena podem ser abordados aproximativamente, a fim de tratar sob outro ângulo da maioria feminina da população escrava. Para tanto, usam-se, na tabela 5, as razões entre os números de crianças (menos de cinco anos) e os de mulheres (idades entre os 15 e os 44 anos). Avalia-se isso no tocante a toda a população escrava da cidade, mas também circunscrevendo uma parte dela em que os fogos receberam algum tipo de classificação, pondo-se de um lado os domicílios escravistas que foram chamados de casas pelos recenseadores, enquanto de outra parte são incluídos os fogos que tenham sido classificados como quintas, ornos, ranchos, rancherias e sitios, conforme procedimento já explicitado acima.

\section{GANPHLAC}

Revista Eletrônica da ANPHLAC, ISSN 1679-1061, №. 23, p. 185-218, Jul./Dez., 2017. http://revista.anphlac.org.br 


\section{Tabela 5}

Razão crianças ( 0 a 4 anos) / mulheres (15 a 44 anos) em Buenos Aires (1778)

\begin{tabular}{lccc}
\hline Faixas de tamanho das escravarias & $\begin{array}{c}\text { Em toda a } \\
\text { população escrava }\end{array}$ & $\begin{array}{c}\text { Nas } \\
\text { "casas" }\end{array}$ & $\begin{array}{c}\text { Nos outros tipos de } \\
\text { estabelecimento* }\end{array}$ \\
\hline 1 a 2 escravos & 0,148 & 0,144 & 0,286 \\
3 a 4 escravos & 0,377 & 0,536 & 0,222 \\
5 a 9 escravos & 0,378 & 0,592 & 1,000 \\
10 a 19 escravos & 0,314 & 0,773 & 0,600 \\
20 ou + escravos & 0,465 & - & 1,200 \\
\hline Total & 0,323 & 0,452 & 0,658 \\
\hline
\end{tabular}

Fonte: UNIVERSIDAD DE BUENOS AIRES, 1919.

Quando se leva em conta a razão criança/mulher vigente para a população em seu conjunto, topa-se com índices bem baixos (comparar com exemplos paulistas em LUNA; KLEIN, 2005, p. 177), algo comum entre escravos alocados em ambientes urbanos. É visível, além disso, que a questão acompanhava diretamente o problema do acesso à formação de famílias, pois esse indicador, que permite aproximação à fecundidade das mulheres escravas, variava em acordo ao tamanho do plantel, e explicálo só pode passar pela consideração de que, maiores as escravarias, maior também a disponibilidade de parceiros para o estabelecimento de uniões. Isso deve ser enfatizado em face de que a parcela masculina da população crescia de acordo com o tamanho dos plantéis, lembrando hipóteses já formuladas por Slenes para o agro exportador paulista (SLENES, 1999, p. 75).

Os tipos mais ruralizados de estabelecimento possivelmente eram marcados por maiores fecundidades das escravas, tendo sido eles, como visto, especificados por maiorias masculinas. Quanto às duas questões, ambas levam a crer que se está diante de expressões de uma demanda muito exacerbada por trabalho, passando tanto por aquisições de homens no mercado, quanto pelo estímulo à formação de famílias escravas. No interior dessa categoria de estabelecimentos, assim como no conjunto da população ou na numerosa categoria dos domicílios classificados como casas, o aumento do tamanho do plantel significava mais famílias, ainda que se note nos mesmos a presença de mais homens.

Além de ser um tema por si mesmo, dado permitir aproximação à questão da mestiçagem, o problema das cores atribuídas aos cativos pelos recenseadores faculta outra abordagem da família escrava. Trata-se disso a partir da tabela 6.

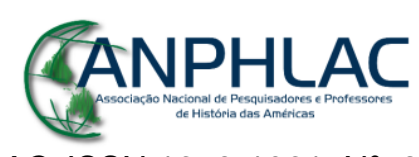

Revista Eletrônica da ANPHLAC, ISSN 1679-1061, №. 23, p. 185-218, Jul./Dez., 2017. http://revista.anphlac.org.br 


\section{Tabela 6}

Cor atribuída aos escravos, por faixa de tamanho das escravarias e de acordo com as faixas etárias dos cativos (Buenos Aires, 1778)

\begin{tabular}{|c|c|c|c|c|c|c|}
\hline \multirow[b]{3}{*}{$\begin{array}{l}\text { Faixas de tamanho } \\
\text { das escravarias }\end{array}$} & \multicolumn{4}{|c|}{ Números absolutos } & & \\
\hline & \multicolumn{2}{|c|}{$\begin{array}{l}\text { Escravos com } 0 \text { a } 11 \\
\text { anos de idade }\end{array}$} & \multicolumn{2}{|c|}{$\begin{array}{c}\text { Escravos com } 12 \text { a } 49 \\
\text { anos de idade }\end{array}$} & \multicolumn{2}{|c|}{$\begin{array}{c}\text { Escravos com } 50 \\
\text { anos de idade ou }+\end{array}$} \\
\hline & A) negros & $\begin{array}{l}\text { B) Outras } \\
\text { cores* }\end{array}$ & C) negros & $\begin{array}{l}\text { D) Outras } \\
\text { cores* }\end{array}$ & $\begin{array}{c}\text { E) } \\
\text { negros }\end{array}$ & $\begin{array}{l}\text { F) Outras } \\
\text { cores* }\end{array}$ \\
\hline 1 a 2 escravos & 89 & 53 & 487 & 160 & 70 & 10 \\
\hline 3 a 4 escravos & 182 & 116 & 490 & 220 & 59 & 17 \\
\hline 5 a 9 escravos & 229 & 168 & 877 & 348 & 123 & 35 \\
\hline 10 a 19 escravos & 107 & 103 & 362 & 211 & 64 & 18 \\
\hline $20 \mathrm{ou}+$ escravos & 31 & 53 & 134 & 83 & 39 & 11 \\
\hline Total & 638 & 493 & 2350 & 1022 & 355 & 91 \\
\hline \multicolumn{7}{|c|}{ Razões } \\
\hline $\begin{array}{l}\text { Faixas de tamanho } \\
\text { das escravarias }\end{array}$ & $\begin{array}{r}\text { Escravos } \\
\text { anos de id } \\
\text { outras cor } \\
\text { (B }\end{array}$ & $\begin{array}{l}\text { om } 0 \text { a } 11 \\
\text { de - razão } \\
\text { s / negros } \\
\text { A) }\end{array}$ & \multicolumn{2}{|c|}{$\begin{array}{c}\text { Escravos com } 12 \text { a } 49 \\
\text { anos de idade - razão } \\
\text { outras cores / negros } \\
\text { (D/C) }\end{array}$} & \multicolumn{2}{|c|}{$\begin{array}{c}\text { Escravos com } 50 \text { ou } \\
+ \text { anos de idade - } \\
\text { razão outros / negros } \\
\text { (F/E) }\end{array}$} \\
\hline 1 a 2 escravos & & & \multicolumn{2}{|c|}{0,3} & \multicolumn{2}{|c|}{0,1} \\
\hline 3 a 4 escravos & \multicolumn{2}{|c|}{0,6} & \multicolumn{2}{|c|}{0,4} & \multicolumn{2}{|c|}{0,3} \\
\hline 5 a 9 escravos & \multicolumn{2}{|c|}{0,7} & \multirow{2}{*}{\multicolumn{2}{|c|}{$\begin{array}{l}0,4 \\
06\end{array}$}} & \multicolumn{2}{|c|}{0,3} \\
\hline 10 a 19 escravos & \multicolumn{2}{|c|}{1,0} & & & \multicolumn{2}{|c|}{0,3} \\
\hline $20 \mathrm{ou}+$ escravos & \multicolumn{2}{|c|}{1,7} & \multicolumn{2}{|c|}{0,6} & \multicolumn{2}{|c|}{0,3} \\
\hline Total & \multicolumn{2}{|c|}{0,8} & \multicolumn{2}{|c|}{0,4} & \multicolumn{2}{|c|}{0,3} \\
\hline
\end{tabular}

Na tabela 6, usa-se como medida simplesmente o resultado da divisão ("razão") do número de escravos de outras cores pelo de cativos classificados como negros, de maneira que razões mais elevadas indicam maior importância da mestiçagem na situação em apreço. Nota-se ali que, para qualquer faixa etária, quanto maior a escravaria, maior a proporção de mestiços entre os escravos. Isso é contraintuitivo. A princípio, esperar-se-ia que nos pequenos plantéis imperasse a busca por uniões com livres, potencializando a mestiçagem pela falta de parceiros potenciais. A expectativa era essa porque, além de terem sido pequenas as unidades escravistas, elas tinham uma população eminentemente feminina. Mas não imperava nos plantéis menores essa busca por parceiros livres que incentivasse a mestiçagem.

Nas maiores escravarias, dava-se o inverso. Parceiros escravos estavam mais disponíveis, e de fato faltavam mulheres, como se viu acima quanto às escravarias com mais de dezenove cativos. Mas era nelas que a mestiçagem se mostrava mais avançada.

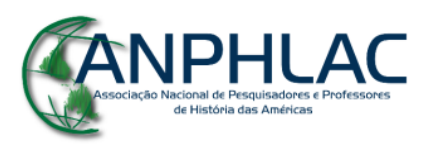

Revista Eletrônica da ANPHLAC, ISSN 1679-1061, №. 23, p. 185-218, Jul./Dez., 2017. http://revista.anphlac.org.br 
Em todas as faixas de tamanho das escravarias, crianças eram mais mestiças que adultos, que por sua vez também eram mais mestiços que os idosos. A diferença entre idosos e adultos plenos é facilmente explicável pelo tráfico de escravos, pois a situação dos de maior idade retrata mais fielmente as condições próprias do início da presença cativa na região.

Já a condição das crianças, comparada à dos adultos, dificilmente pode ser explicada pelo tráfico. Sendo a população escrava urbana predominantemente feminina, a importância do comércio de almas para configurá-la não deve ter sido muito grande.

Intervinha, além do mais, o que se chama por vezes de mestiçagem classificatória. Quanto ao Brasil, já se escreveu sobre a tendência a serem tratados como "pardos" os escravos que, sem o serem "biologicamente", enfrentavam com sucesso os quase imperceptíveis canais disponíveis de modesta mobilidade ascendente (MATTOS, 1995, p. 84-88; BARICKMAN, 1999). Também já se escreveu, tendo em vista a escravidão brasileira, que a mestiçagem classificatória, ao invés de responder à mobilidade ascendente de uma maneira individual, podia, na verdade, consagrar uma expectativa de que se produzissem seres dóceis no interior do cativeiro (LIMA, 2015). Entendendo mestiços como mediadores, ou como uma espécie de anteparo da ordem social hierárquica, premiava-se com o rótulo aqueles que aproveitavam as brechas de uma mobilidade que se julgava apaziguadora, ou então se usava a pecha preferencialmente em relação a grupos inteiros que pudessem ser vistos como submissos, o que, em uma ordem rudemente patriarcal, atingia em cheio mulheres e crianças.

Identificar esse elemento classificatório permite retomar a incidência diferencial da mestiçagem conforme a abastança senhorial. É plausível supor que uma parte impossível de discernir dessa diferença derivasse de sistemas de classificação independentes de origens e fenótipos. É plausível que interferissem mecanismos putativos, da ordem dos vieses da classificação, mais que da observação. Haveria, assim, uma tendência a ver negros nas casas dos senhores menos prósperos e mestiços, nas dos proprietários mais ricos. Nessa sociedade hierárquica, nas últimas estaria o modelo de convívio; no modelo, portanto, a mestiçagem e seu impacto inclusivo.

\section{CANPHLAC}

Revista Eletrônica da ANPHLAC, ISSN 1679-1061, №. 23, p. 185-218, Jul./Dez., 2017.

http://revista.anphlac.org.br 


\section{Considerações finais}

Como sempre, o estudo da estrutura de posse de escravos foi aqui extremamente revelador acerca de aspectos importantes da desigualdade social vigente, inclusive, entre as pessoas livres. A análise do caso portenho, comparado ao do Rio de Janeiro, indicou diferentes formas de desigualdade, embora se tenha tratado de formas no fim das contas comparáveis, apesar do lugar diverso ocupado pelo cativeiro em cada uma delas. O mesmo confronto sugeriu, ademais, que a disparidade entre as condições dos livres atravessava todo o corpo social, não se tendo limitado a se exprimir através da grande distância entre a cúpula da hierarquia e o conjunto de uma sociedade, que se poderia ver como plana e indiferenciada. O caráter ao mesmo tempo hierárquico e inclusivo da distribuição da posse de escravos implicava, juntamente com outras facetas da vida social, a vigência de inúmeras distinções entre pessoas livres, as quais, embora menos visíveis, não eram menos efetivas.

O campo ao redor de Buenos Aires, ainda pouco ocupado em termos coloniais, exercia uma atração sobre os ativos que impactava as relações escravistas urbanas, ao menos no momento observado, de relativa retração. Até mesmo as atividades agrárias que se desenrolavam na abrangência administrativa da cidade exerciam essa tração. Possivelmente, era a rarefação da ocupação da campanha, derivada por sua vez da insegurança, o que permitia que tantos escravos ainda se concentrassem no núcleo urbano, que pode ter sido a maior cidade com escravos da América do Sul.

Diferiram os tipos de escravidão urbana implantados nas Américas, produzindo comunidades escravas muito diversas entre si. Aqui, isso pôde ser examinado levando em conta a presença relativa de homens e mulheres na população. Isso distinguiu Buenos Aires e Bogotá dos casos do Rio de Janeiro, Salvador, Lima e Caracas.

Talvez contraditoriamente, a mestiçagem e a família escrava (aqui entrevista através de um indicador indireto da fecundidade das cativas) acompanhavam positivamente o tamanho das escravarias. Isso indica que a miscigenação e a formação de laços se ligavam à consolidação senhorial. Tratava-se de uma espécie de projeto de sociedade, centrado em correias de transmissão, o que também pode ser entrevisto por intermédio do problema da mestiçagem classificatória. A concomitância entre a complexidade dos fogos, ou a quantidade de dependentes neles presentes, e o tamanho

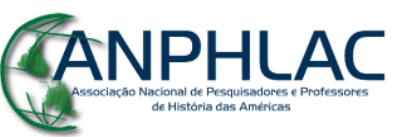

Revista Eletrônica da ANPHLAC, ISSN 1679-1061, №. 23, p. 185-218, Jul./Dez., 2017. http://revista.anphlac.org.br 
das escravarias ia na mesma direção: possivelmente, séquitos de livres e de escravos se reforçavam mutuamente.

Pode-se avançar a hipótese de que a relação positiva entre tamanho da escravaria e sinais de mestiçagem, assim como entre o primeiro elemento e a família cativa, ligavase a características fundamentais da escravidão enquanto tal. Se todo cativeiro aponta para dessocialização (MEILLASSOUX, 1992) e morte social (PATTERSON, 2008; MILLER, 2012, p. 21), isso certamente se tornava ainda mais dramático no isolamento das pequenas escravarias urbanas. Nas maiores, inversamente, os aspectos cruelmente inclusivos da hierarquia social (e da desigualdade) podiam ser acionados com violência, caindo em campo comparativamente fértil, em virtude daquelas características intrínsecas ao cativeiro. Os maiores plantéis ofereciam aos escravos possibilidades um tanto maiores de inclusão no que toca a laços simétricos ou em relação aos livres circundantes, mas também quanto aos vínculos assimétricos, o que se verifica por intermédio da mestiçagem, fosse ela real, fosse ela classificatória, pois a mesma enfrentava, consolidando-se, até a plena disponibilidade de parceiros no interior dos grandes plantéis.

\section{Referências Bibliográficas}

ANDRADE, Maria José de Souza. A mão de obra escrava em Salvador, 1811-1860. São Paulo: Corrupio; Brasília: CNPq, 1988.

Archivo General de la Nación, Consulado de Buenos Aires - actas - documentos. Buenos Aires: Guillermo Kraft, 1947.

ARROYO ABAD, Leticia; DAVIES, Elwyn; VAN ZANDEN, Jan Luiten. Between conquest and Independence: real wages and demographic change in Spanish America, 1530-1820. Explorations in Economic History, Nashville, n. 49, p. 149-166, 2012.

AZCUY AMEGHINO, Eduardo; BIROCCO, Carlos María. As colônias do Rio da Prata e o Brasil: geopolítica, poder, economia e sociedade (séculos XVII e XVIII). In: CERVO, Amado Luiz; RAPOPORT, Mario (Orgs.). História do Cone Sul. Rio de Janeiro: Revan; Brasília: Editora Universidade de Brasília, 1998.

BARICKMAN, B. J. As cores do escravismo: escravistas 'pretos', 'pardos' e 'cabras' no Recôncavo Baiano em 1835. População e Família, São Paulo, v. 2, n. 2, pp. 7-62, 1999.

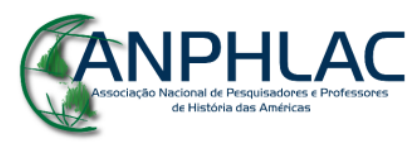

Revista Eletrônica da ANPHLAC, ISSN 1679-1061, №. 23, p. 185-218, Jul./Dez., 2017. http://revista.anphlac.org.br 
BENITO HIERRO, Carmen. Esclavos y afrodescendientes en el Buenos Aires del siglo XVIII. Naveg@mérica, Murcia, n. 15, 2015. Disponível em: http://revistas.um.es/ navegamerica/article/view/241441 Acesso em: 06 set. 2016.

BORUCKI, Alex. Las rutas brasileñas del tráfico de esclavos hacia el Río de la Plata, 1777-1812. IV Encontro Escravidão e Liberdade no Brasil Meridional - Anais. Curitiba: UFPR, p. 1-16, 2009.

COMADRÁN RUIZ, Jorge. Evolución demográfica argentina durante el periodo hispano (1535-1810). Buenos Aires: Editorial Universitaria de Buenos Aires, 1969.

CRUZ BARNEY, Óscar. El régimen jurídico de los Consulados de Comercio indianos: 1784-1795. México: IIJ-UNAM, 2001.

CUESTA, Eduardo Martín. Impuestos imperiales: la Caja Real de Buenos Aires (17001800). Temas de Historia Argentina y Americana, Buenos Aires, n. XIV, p. 27-56, 2009.

CUESTA, Martin. Precios y mercados en Buenos Aires en el siglo XVIII. América Latina en la Historia Económica, México, n. 28, p. 25-57, 2007.

CUESTA, Martín. Evolución de la población y estructura ocupacional de Buenos Aires, 1700-1810. Papeles de población, Toluca, n. 49, p. 205-238, 2006.

DJENDEREDJIAN, Julio. La agricultura pampeana en la primera mitad del siglo XIX. Historia del capitalismo agrario pampeano, tomo 4. Buenos Aires: Siglo XXI, 2008.

DOERING, Juan Günther; LOHMAN VILLENA, G. Lima. Madri: Mapfre, 1992.

FERRY, Robert J. The colonial elite of early Caracas. Formation \& crisis, 1567-1767. Berkeley: University of California Press, 1989.

FLORENTINO, Manolo. Em costas negras. São Paulo: Companhia das Letras, 1997.

FRADKIN, Raúl O. El mundo rural colonial. In: TANDETER, Enrique (Org.). La sociedad colonial. Nueva Historia Argentina, tomo II. Buenos Aires: Sudamericana, 2000.

GARAVAGLIA, Juan Carlos. Las actividades agropecuarias en el marco de la vida económica del pueblo de indios de Nuestra Señora de los Santos Reyes Magos de Yapeyú: 1768-1806. In: FLORESCANO, Enrique (Coord.). Haciendas, latifundios y plantaciones en América Latina. $2^{a}$ ed., México: Siglo XXI, 1978.

GELMAN, Jorge Daniel. De mercachifle a gran comerciante: los caminos del ascenso en el Río de la Plata Colonial. La Rábida: Universidad Internacional de Andalucía; Buenos Aires: Universidad Nacional de Buenos Aires, 1996.

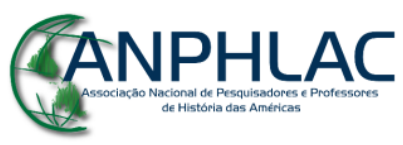

Revista Eletrônica da ANPHLAC, ISSN 1679-1061, №. 23, p. 185-218, Jul./Dez., 2017. http://revista.anphlac.org.br 
GELMAN, Jorge. Derechos de propiedad, crecimiento económico y desigualdad en la región pampeana, siglos XVIII y XIX. Historia agraria, Murcia, n. 37, p. 467-488, 2005 .

GOLDBERG, Marta. La población 'negra', desde la esclavitud hasta los afrodescendientes actuales. In: OTERO, Hernán (Dir.). Población, ambiente y territorio. Buenos Aires: Edhasa, 2012.

GOLDBERG, Marta; MALLO, Silvia Cristina. La población africana en Buenos Aires y su campaña. Formas de vida y subsistência. Temas de África y Asia 2. Buenos Aires: Facultad de Filosofía y Letras, UBA, p. 15-69, 1994.

GRUPO DE INVESTIGACIÓN EN HISTORIA RURAL RIOPLATENSE. La sociedad rural bonaerense a principios del siglo XIX. Un análisis a partir de las categorías ocupacionales. In: FRADKIN, Raul O.; GARAVAGLIA, Juan Carlos (Eds.). En busca de un tiempo perdido. La economía de Buenos Aires en el País de la Abundancia, 17501865. Buenos Aires: Prometeo, 2004.

GUZMÁN, Florencia. Africanos en la Argentina. Una reflexión desprevenida. Andes, Salta, n. 17, p. 1-35, 2006.

HALPERIN-DONGHI, Tulio. Una estancia en la campaña de Buenos Aires. Fontezuela, 1753-1809. In: FLORESCANO, Enrique (Coord.). Haciendas, latifundios y plantaciones en América Latina. 2a ed., México: Siglo XXI, 1978.

JOHNSON, Lyman L. 'A lack of legitimate obedience and respect': slaves and their masters in the Courts of Late Colonial Buenos Aires. Hispanic American Historical Review, v. 87, n. 4, 2007.

JUMAR, Fernando; PAREDES, Isabel. El comercio intrarregional en el complejo portuario rioplatense: el contrabando visto a través de los comisos, 1693-1777. América Latina en La Historia Económica, México, n. 29, p. 31-98, 2008.

KRASELSKY, Javier. De la centralización corporativa a la formación de estados autónomos: aportes para un modelo analítico local. El caso del puerto de Buenos Aires, 1779-1814. Primeras Jornadas de Historia Económica. Asociación Mexicana de Historia Económica - Anales. México: AMHE, p. 1-28, 2012.

LIMA, Carlos Alberto M. Artífices do Rio de Janeiro. Rio de Janeiro: Apicuri, 2008.

LIMA, Carlos Alberto M. Avanço, arbitrariedade e variabilidade na classificação como mestiços de escravos nascidos no Brasil (séculos XVIII e XIX). Anais de História de Além-Mar, Lisboa, v. XVI, p. 339-365, 2015.

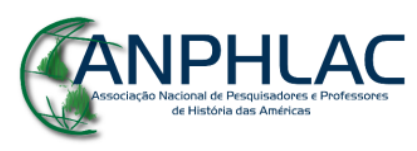

Revista Eletrônica da ANPHLAC, ISSN 1679-1061, №. 23, p. 185-218, Jul./Dez., 2017. http://revista.anphlac.org.br 
LÓPEZ, Cristina del Carmen. El espacio y la gente: la dinámica sociodemográfica de la población del Tucumán tardo y poscolonial, Andes, Salta, n. 17, 2006. Disponível em: http://www.redalyc.org/html/127/12701706/> Acesso em: 06 out. 2016.

LOWRY, Lyn. Grietas en la ciudad, grietas en el sistema colonial: migración y identidad andina en Lima colonial. In: FONSECA, Claudia (Org.). Fronteiras da cultura. Porto Alegre: Ed. Universidade/UFRGS, 1993.

LUNA, Francisco Vidal; KLEIN, Herbert. Evolução da sociedade e economia escravista de São Paulo, de 1750 a 1850. São Paulo: Edusp, 2005.

MAGO DE CHÓPITE, Lila. La población de Caracas (1754-1820). Estructura y características. Anuario de Estudios Americanos, Sevilha, t. LIV, n. 2, p. 511-541, 1997.

MALLO, Silvia Cristina. El color del delito en Buenos Aires. 1750-1830. Memoria \& sociedad, Bogotá, v. 7, n. 15, p. 111-123, 2003.

MALLO, Silvia. Población africana en el Río de la Plata: delito, adaptación y negociación. In: LARRAMENDI, F. de (Ed.). La vida cotidiana de los negros en Hispano América. Madrid: Proyectos Históricos Tavera, 2005.

MASSÉ, Gladys. El tamaño y el crecimiento de la población desde la conquista hasta 1870. In: OTERO, Hernán (Dir.). Población, ambiente y territorio. Historia de La provincia de Buenos Aires, v. 1. Buenos Aires: Edhasa, 2012.

MATTOS, Hebe. Das Cores do Silêncio. Rio de Janeiro: Arquivo Nacional, 1995.

MEILLASSOUX, Claude. Antropologia da escravidão. Rio de Janeiro: Jorge Zahar, 1992.

MERCADER, J.; DOMÍNGUEZ, A. La época del Despotismo Ilustrado. In: VICENS VIVES, J. (Dir.). Historia de España y América. Social y económica, vol. IV. Barcelona: Vicens-bolsillo, 1972.

MILLER, Joseph C. A abolição como um discurso de apreensão cívica: escravidão como abominação pública. In: XAVIER, Regina Célia Lima (Org.). Escravidão e liberdade. São Paulo: Alameda, 2012.

MORENO, José Luis. Población y sociedad en el Buenos Aires rural a mediados del siglo XVIII. Desarrollo Económico, Buenos Aires, v. 29, n. 114, p. 265-282, 1989.

MORENO, José Luis. La estructura social y demográfica de la ciudad de Buenos Aires en el año 1778. Anuario del Instituto de Investigaciones Históricas, Rosario, n. 8, p. 151-170, 1965.

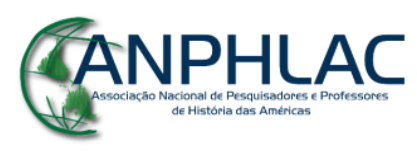

Revista Eletrônica da ANPHLAC, ISSN 1679-1061, №. 23, p. 185-218, Jul./Dez., 2017.

http://revista.anphlac.org.br 
MOTTA, José Flávio; NOZOE, Nelson; COSTA, Iraci del Nero da. Às vésperas da abolição: um estudo sobre a estrutura de posse de escravos em São Cristóvão (RJ), 1870. Estudos econômicos, São Paulo, v. 34, n. 1, p. 157-213, 2004.

ODDONE, Juan A. El comercio rioplatense ante la crisis del orden colonial. In: BAGÚ, Sergio et al. De historia e historiadores: homenaje a José Luis Romero. México: Siglo XXI, 1982.

OLIVERO, Sandra. Espacio vital y espacio físico: el hogar y la vivienda en el Buenos Aires colonial. In: LORETO LÓPEZ, Rosalva (Coord.). Perfiles habitacionales y condiciones ambientales. Historia urbana de Latinoamérica siglos XVII-XX. Puebla: Benemérita Ciudad Autónoma de Puebla/ Consejo Nacional de Ciencia y Tecnología/ Deutsches Museum, 2007.

OTERO, Osvaldo. Vivienda y poder: la sociedad urbana en el Buenos Aires tardocolonial. Nuevo Mundo - Mundos Nuevos, Paris, 2010. Disponível em: https://nuevomundo.revues.org Acesso em: 20 ago. 2016.

PATTERSON, Orlando. Escravidão e morte social. São Paulo: Edusp, 2008.

PEREDA VALDES, Ildefonso. El negro en el Uruguay. Pasado y presente. Montevideo: Revista del Instituto Histórico y Geográfico del Uruguay, 1965.

REBAGLIATI, Lucas. Los pobres ante la justicia: discursos, prácticas y estrategias de subsistencia en Buenos Aires (1785-1821). Boletín del Instituto de Historia Argentina y Americana “Doctor Emilio Ravignani”, Buenos Aires, n. 38, p. 11-41, 2013.

REITANO, Emir. La inmigración antes de la inmigración. Los portugueses de Buenos Aires en vísperas de la Revolución de Mayo. Mar del Plata: Eudem, 2010.

ROCK, David. Argentina, 1516-1987. From Spanish colonization to Alfonsín. Berkeley: University of California Press, 1987.

ROMANO, Ruggiero. Coyunturas opuestas. La crisis del siglo XVII en Europa e Hispanoamérica. México: Fondo de Cultura Económica, 1993.

ROSAL, Miguel Á. Diversos aspectos relacionados con la esclavitud en el Río de la Plata a través del estudio de testamentos de afroporteños, 1750-1810. Revista de Indias, v. LVI, n. 206, p. 219-235, 1996.

ROSAL, Miguel Ángel. Negros y pardos em Buenos Aires, 1811-1860. Anuario de estudios americanos, Sevilha, tomo LI, n. 1, p. 165-184, 1994.

ROSAL, Miguel Á. Manumisiones de esclavos en Buenos Aires (1609-1659). In: GHIDOLI, María de Lourdes; MARTÍNEZ PERIA, Juan Francisco (Comp.). Estudios afrolatinoamericanos. Nuevos enfoques interdisciplinarios. Actas de las Terceras

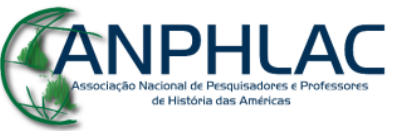

Revista Eletrônica da ANPHLAC, ISSN 1679-1061, №. 23, p. 185-218, Jul./Dez., 2017. http://revista.anphlac.org.br 
Jornadas del GEALA. Buenos Aires: Ediciones del Centro Cultural de la Cooperación Floreal Gorini, p. 287-311, 2013.

SAGUIER, Eduardo. La naturaleza estipendiaria de la esclavitud urbana colonial. El caso de Buenos Aires en el siglo XVIII. Revista Paraguaya de Sociología, Assunção, ano 26, n. 74, p. 45-55, 1989.

SAGUIER, Eduardo R. La crisis revolucionaria en el Paraguay y el comportamiento de la milicia. La Real Renta del Tabaco como motor de la crisis agraria colonial. Folia Histórica del Nordeste, Resistencia, n. 11, p. 65-92, 1993.

SCHWARTZ, Stuart B. Segredos internos: engenhos e escravos na sociedade colonial, 1550-1835. São Paulo: Companhia das Letras; Brasília: CNPq, 1988.

SECRETO, María Verónica. Justiça na desigualdade: ações de liberdade, "papéis de venda" e "justo preço", Rio da Prata, 1776-1815. Afro-Ásia, Salvador, n. 42, p. 27-62, 2010.

SLENES, Robert. Na senzala, uma flor. Rio de Janeiro: Civilização Brasileira, 1999.

SOCOLOW, Susan. Los mercaderes del Buenos Aires virreinal: familia y comercio. Buenos Aires: La Flor, 1991.

TANDETER, Enrique; WACHTEL, Nathan. Precios y producción agraria. Potosí y Charcas en el siglo XVIII. Buenos Aires: Estudios CEDES, s/d.

UNIVERSIDAD DE BUENOS AIRES. Documentos para la historia argentina. Buenos Aires: Compañía Sud-Americana de Billetes de Banco, 1919, t. XI ("Territorio y población. Padron de la ciudad de Buenos Aires [1778]").

VALENCIA VILLA, Carlos Eduardo. En procura de la libertad en las dos puntas de un hilo: la manumisión entre los esclavos de Río de Janeiro y Bogotá en el siglo XIX. In: ALZATE ECHEVERRI, Adriana Maria; FLORENTINO, Manolo; VALENCIA, Carlos Eduardo (Orgs.). Impérios Ibéricos em Comarcas Americanas. Estudos regionais de história colonial brasileira e neogranadina. Rio de Janeiro: Programa de Pós-Graduação em História Social da UFRJ / Ed. 7 Letras, 2010.

VIGLIONE, Hebe M. L. Análisis de la población esclava de los pagos del Litoral Fluvial de Buenos Aires y Santa Fé, 1815-16. In: IX Jornadas Argentinas de Estudios de Población. Córdoba: AEPA, p. 1-18, 2007.

VILAR, P. La Catalogne dans l'Espagne moderne. Paris: Le Sycomore/EHESS, 1982.

WAINER, Luis E. La ciudad de Buenos Aires en los censos de 1778 y 1810. Población de Buenos Aires, Buenos Aires, v. 7, n. 11, p. 75-85, 2010.

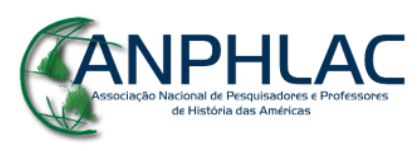

Revista Eletrônica da ANPHLAC, ISSN 1679-1061, №. 23, p. 185-218, Jul./Dez., 2017.

http://revista.anphlac.org.br 
WELLS, John. Distribuição de rendimentos, crescimento e a estrutura de demanda no Brasil na década de 60. Revista de Administração de Empresas, Rio de Janeiro, v. 14, n. 2, p. 21-44, 1974. 